
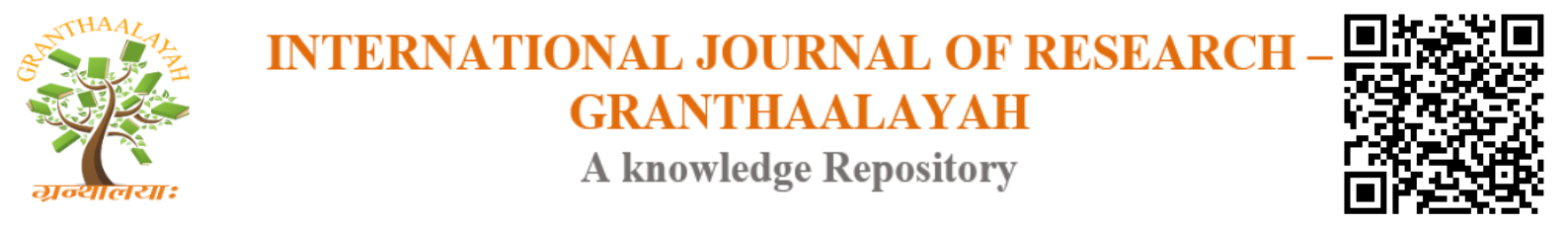

Management

\title{
AN APPRAISAL OF EMPLOYEES WELFARE AND SOCIAL SECURITY MEASURES IN CENTRAL PUBLIC SECTOR ENTERPRISES
}

\author{
Joyjit Sanyal ${ }^{1}$, Dr. Sujit Sikidar ${ }^{2}$ \\ ${ }^{1}$ Assistant Professor, Department of Commerce, Assam University Diphu Campus, Diphu, Karbi \\ Anglong, Assam, India \\ ${ }^{2}$ Professor (Retired), Department of Commerce, Gauhati University, Guwahati, Assam, India
}

\begin{abstract}
Labour plays a very important role in the industrial production of the country. The human resource managers are concerned with the management of people at work. It is necessary to secure the cooperation of labour force in order to increase the production and earn higher profits. The cooperation of labour force is possible only when they are fully satisfied with their employer and the working conditions on the job. In the past, industrialists and the employers believed that their only duty towards their employees was to pay them satisfactory wages and salaries. But in due course of time, in addition to providing monetary benefits, human treatment given to employees started to play a very important role in seeking their co-operation. Labour or employee welfare activities benefit not only the workers but also the management in the form of greater industrial efficiency. The welfare activities pay a good dividend in the long run, because they contribute a lot towards the health and efficiency of the workers and towards a high morale.

On the other hand, social security has come up as a dynamic concept which is considered in all advanced countries of the world as an indispensable chapter of the national programme. Social security is that security which the society furnishes through appropriate organisation against certain risks or certain contingencies to which its members are exposed. These risks are essentially contingencies against which the individual cannot afford by his small means and by his ability or foresight alone. As the name stands for general well- being of the people it is the duty of the state to promote social security which may provide the citizens with benefits designed to prevent or cure disease, to support him when he is not able to earn and to restore him to gainful activity.

The state as an employer has provided for certain measures for the welfare and social security of the labourers, who contribute towards the economic development of a country and in this regard, the government has to see towards the proper implementation of such measures to maintain a harmonious industrial relation on the one side and on the other hand towards the upliftment of the members of the society.

Thus, there arise the vital needs for the detailed assessments of the measures so provided, its quality of implementation so far and the level of satisfaction of the same among the different class of employees.

The present study acts as a working paper with an objective to gather the opinion of the organized workforce in the Central Public Sector Enterprises with regards to their acceptance and satisfaction level of the various 'Employees welfare and Social Security' measures by the employers.
\end{abstract}


However, the present study is restricted to two enterprises only and is undertaken with the following objectives:

- $\quad$ To analyze the opinions of the employees in respect of the labour welfare measures \& social security benefits.

- To analyze the level of satisfaction or otherwise of the workers in respect of social security measures.

Keywords: Labour Welfare; Social Security; Job Satisfaction.

Cite This Article: Joyjit Sanyal, and Dr. Sujit Sikidar. (2018). "AN APPRAISAL OF EMPLOYEES WELFARE AND SOCIAL SECURITY MEASURES IN CENTRAL PUBLIC SECTOR ENTERPRISES.” International Journal of Research - Granthaalayah, 6(7), 234-247. https://doi.org/10.29121/granthaalayah.v6.i7.2018.1303.

\section{Introduction}

The term welfare is so comprehensive that it leads to various interpretations and meaning. The term "welfare" is derived from the French phrase welfare which means to "fare well". Welfare is a broad concept refers to the state of living of an individual or a group in a desirable relationship with the total environment- ecological, economic and social. After basic pay and incentives, the third major components of organizational reward system is welfare and social security benefits some of which are mandated by law and some are voluntary. Adequate levels of earnings, safe and humane conditions of work and access to some minimum social security benefits are the major qualitative dimensions of employment which enhances quality of work life of workers and their productivity.

\section{Meaning of Employee Welfare}

According to the Oxford dictionary, employee welfare means "the effort to make life worth living for workmen." In the words of Arthur James Todd, "Employee's welfare means anything done for the comfort and improvement, intellectual or social, of the employees over and above the wages paid which is not a necessity of the industry. "Welfare includes anything that is done for the comfort and improvement of employees and is provided over and above the wages. Welfare helps in keeping the morale and motivation of the employees high so as to retain the employees for longer duration. The welfare measures need not be in monetary terms only but in any kind/ forms. Employee welfare includes monitoring of working conditions, creation of industrial harmony through infrastructure for health, industrial relations and insurance against diseases, accident and unemployment for the workers and their families. Employee welfare entails all those activities of employer which are directed towards providing the employees with certain facilities and services in addition to wages and salaries. It implies the setting up of minimum desirable standards and the provision of facilities like health, food, clothing, housing, medical, assistance, recreational, educational, consumer cooperative stores etc.

Employee welfare has acquired an important place in the modern commercial world. 
The main aim of the employee's welfare is to establish and maintain relationship at all levels of management by giving satisfactory conditions of employment and also provide fairly for the requirement. The modern industrial welfare covers the entire gamut of activities undertaken to secure to the industrial workers an essentially human status, to make him a better citizen and to improve his efficiency and economic position. The Indian Oil Corporation Limited has done a lot in respect of providing welfare facilities for their employees. Employee's welfare work can be broadly divided into three categories: (i) statutory welfare. (ii) Non-statutory Welfare and (iii) Social Securities benefits.

\section{Meaning of Social Security}

Social security is a system of protection or support provided by the society or government to workers and their families in time of sudden calamity, sickness, unemployment, injuries, industrial accidents, disablement, old age or other contingencies.

Social security is one of the key components of employee welfare. Employees' welfare refers to all such services, amenities and facilities to the employees that improve their working conditions as well as standard of living. Social security benefits provided by an enterprise should protect not only their employees but also their family members through financial securities including health care. Social security's envisage that the employees shall be protected against all types of social risks that may cause undue hardships to their in fulfilling their basic needs.

The term 'social security' originated in USA and was used to establish schemes of unemployment and old-age insurance in 1935. In 1938, the same term was used by New Zealand when it created social security system- a measure of income security for all citizens.

According to ILO, "Social security is that security that society furnishes through appropriate organization against certain risks to which its members are exposed. These risks being sickness, maternity, invalidity, old-age and death. It is for contingencies that affect the ability of working man to support himself and his dependents in health and decency."

The concept of social security is essentially related to the high ideas of human dignity and social justice. It has become a major aspect of public policy in most countries. It yields benefits in the long- run.

Social Security Programmes includes Medicare and insurance benefits, medical help at the time of injury and accident and provision financial compensation and relief. Pension in case of disablement, Unemployment insurance or allowance, Maternity benefits, Death payments and family pension, Retirement benefits or old age relief etc.

\section{Social Security in India}

India is a welfare state as envisaged in her constitution. Article 41 of our constitutional lays down, "the state shall within limits of its economic capacity and development make effective provision securing the right to work, to education and to public assistance in case of unemployment, old-age, sickness etc. In India, provision for social security to the worker occupies a very important place 
in the industrial set up. It is included in our Constitution under the Directive Principles of State Policy. It thus makes the 'State' bear the primary responsibility for developing an appropriate system for protecting and assisting its workforce. Hence, a Social Security Division has been set up under the Ministry of Labour and Employment. The division deals with framing of Social security policy for the workers, administration of all the legislations relating to social security and implementation of the various Social Security Schemes.

Several laws enacted are:

1) Employee's State Insurance Act, 1948 (ESI). Some benefits to contributors are:

- $\quad$ Sickness benefit and medical benefit

- Maternity benefit and disablement benefit and

- Dependents benefit (window and children), funeral benefits.

2) Employees Provident Fund Act, 1952

3) Payment of Gratuity Act, 1972

4) Workmen's Compensation Act,1923

5) The Maternity Benefit Act, 1961

6) Old-age pensions by state governments

7) Public health facilities by government.

8) Social security to unemployed workers by ESIC.

9) Employment Guarantee Act, 2005.

\section{Employee's Welfare Benefits}

It is useful to consider welfare benefits under three basic categories viz., (i) Statutory welfare facilities (ii) Non-statutory welfare facilities and (iii) social securities benefits

\begin{tabular}{|c|c|c|}
\hline Statutory Welfare Facilities & Non-Statutory Welfare Facilities & Social Security Benefits \\
\hline $\begin{array}{ll}\text { - } & \text { Washing facilities } \\
\text { - } & \text { Drinking water facilities } \\
\text { - } & \text { First-aid box facilities } \\
\text { - } & \text { Rest shelter facilities } \\
\text { - } & \text { Crèches } \\
\text { - } & \text { Sitting Facilities } \\
\text { - } & \text { Canteens } \\
\text { - } & \text { Storing \& drying clothes } \\
& \text { facilities }\end{array}$ & $\begin{array}{ll}\text { - } & \text { Medical facilities } \\
\text { - } & \text { Educational facilities } \\
\text { - } & \text { Recreational facilities } \\
\text { - } & \text { Housings } \\
\text { - } & \text { Consumer cooperative stores } \\
\text { - } & \text { Cooperative credit society } \\
\text { - } & \text { Transportation Facilities }\end{array}$ & $\begin{array}{ll}\text { - } & \text { Provident Fund } \\
\text { - } & \text { Gratuity } \\
\text { - } & \text { Pension } \\
\text { - } & \text { Maternity benefits } \\
\text { - } & \text { Insurance benefits } \\
\text { - } & \text { Accidental benefits }\end{array}$ \\
\hline
\end{tabular}




\section{Review of Literature}

(A) THESIS

\begin{tabular}{|c|c|c|c|c|}
\hline $\begin{array}{c}\text { Serial } \\
\text { no. }\end{array}$ & $\begin{array}{c}\text { Name of the } \\
\text { author(s) }\end{array}$ & Year & Title of the paper & Findings \\
\hline 1 & Srivastava & 1953 & $\begin{array}{l}\text { "Employee Welfare } \\
\text { in India" detailed } \\
\text { upon the employee } \\
\text { welfare measures } \\
\text { undertaken by } \\
\text { selected public and } \\
\text { private sector } \\
\text { companies in India. }\end{array}$ & $\begin{array}{l}\text { He found that public sector } \\
\text { companies are far better than their } \\
\text { private companies in the provision of } \\
\text { welfare facilities to workers and } \\
\text { employees. }\end{array}$ \\
\hline 2 & Omprakash Verma & $\begin{array}{l}1958- \\
1965\end{array}$ & $\begin{array}{l}\text { "Employee's Welfare } \\
\text { And Industrial Peace } \\
\text { in India" }\end{array}$ & $\begin{array}{l}\text { He stated that many industries failed } \\
\text { to provide adequate welfare facilities } \\
\text { to their employees due to which } \\
\text { industrial unrest had become a } \\
\text { common phenomenon among } \\
\text { various industries. }\end{array}$ \\
\hline 3 & Badhwan & $\begin{array}{l}1959- \\
1964\end{array}$ & $\begin{array}{l}\text { "Workmen's } \\
\text { Compensation } \\
\text { Act,1923- with } \\
\text { special reference to } \\
\text { Coal Mining } \\
\text { Industries in India" }\end{array}$ & $\begin{array}{l}\text { He stated that the compensation paid } \\
\text { to coal miners who died in mine } \\
\text { accidents is very low. Hence, he felt } \\
\text { the need for increasing the } \\
\text { compensation payable to employees. }\end{array}$ \\
\hline 4 & DharamVeersingh & $\begin{array}{l}1963- \\
1967\end{array}$ & $\begin{array}{l}\text { "Social And } \\
\text { Economic Welfare } \\
\text { Services in Uttar } \\
\text { Pradesh" }\end{array}$ & $\begin{array}{l}\text { He found that the successive } \\
\text { government after independence } \\
\text { could not provide the required social } \\
\text { and economic welfare services to the } \\
\text { needy people due to which many } \\
\text { people are living below the poverty } \\
\text { line. }\end{array}$ \\
\hline 5 & Sharma & 1974 & $\begin{array}{l}\text { "Living Condition of } \\
\text { Colliery Workers in } \\
\text { Jharia Coal Fields" } \\
\text { examined the } \\
\text { working and living } \\
\text { conditions of workers } \\
\text { and employees in } \\
\text { Jharia Coal Fields. }\end{array}$ & $\begin{array}{l}\text { The study found that the working and } \\
\text { living condition of workers and } \\
\text { employees who are working in the } \\
\text { mines are very poor and hence the } \\
\text { living condition need to be improved } \\
\text { a lot. }\end{array}$ \\
\hline
\end{tabular}




\begin{tabular}{|c|c|c|c|c|}
\hline 6 & Subba Rao & 1980 & $\begin{array}{l}\text { "Women Welfare in } \\
\text { Jute Industry (A } \\
\text { Study on Welfare } \\
\text { Programmes in } \\
\text { selected Jute Mills } \\
\text { Eluru in Andhra } \\
\text { Pradesh" }\end{array}$ & $\begin{array}{l}\text { The study revealed that these } \\
\text { companies have to do a lot in the } \\
\text { area of welfare for the betterment of } \\
\text { women employees. }\end{array}$ \\
\hline 7 & Sambasiva Rao & 1996 & $\begin{array}{l}\text { "A study of Welfare, } \\
\text { Health and Safety of } \\
\text { Workers in the } \\
\text { Cement Industry of } \\
\text { Guntur District in } \\
\text { Andhra Pradesh". }\end{array}$ & $\begin{array}{l}\text { The study found that large cement } \\
\text { companies provide better health, } \\
\text { safety and welfare measures as } \\
\text { compared to small and medium scale } \\
\text { cement companies. }\end{array}$ \\
\hline 8 & $\begin{array}{l}\text { A.Sabarirajan, } \\
\text { T.Meharajan, } \\
\text { B.Arun }\end{array}$ & 2001 & $\begin{array}{l}\text { "Employee welfare } \\
\text { in Textile industries". }\end{array}$ & $\begin{array}{l}\text { The study shows that } 15 \% \text { of } \\
\text { employees are satisfied with their } \\
\text { welfare measures. } 39 \% \text { of the } \\
\text { employee is average with their } \\
\text { welfare measures. } 16 \% \text { of them are } \\
\text { highly dissatisfied level. This study } \\
\text { throws light on the impact of welfare } \\
\text { measures on QWL among the } \\
\text { employees of textile mills in Salam } \\
\text { district. }\end{array}$ \\
\hline 9 & Moulvi & 2003 & $\begin{array}{l}\text { "Impact of Social } \\
\text { Security-cum- } \\
\text { Employee Welfare } \\
\text { Measures on } \\
\text { Production, } \\
\text { Absenteeism and } \\
\text { Attitudes of } \\
\text { Industrial Worker- A } \\
\text { comparative study of } \\
\text { KSRTC Regional } \\
\text { work shop of Hubli } \\
\text { and Bangalore" }\end{array}$ & $\begin{array}{l}\text { He found that the productivity of the } \\
\text { workers has increased with the } \\
\text { provision of welfare facilities. } \\
\text { Further, employees have formed } \\
\text { positive attitudes. However, } \\
\text { provision of social security and } \\
\text { welfare measures has not helped in } \\
\text { the reduction of absenteeism. }\end{array}$ \\
\hline 11 & Viswanand & 2008 & $\begin{array}{l}\text { "A Study on Welfare } \\
\text { Facilities and its } \\
\text { Impact on the } \\
\text { Efficiency of } \\
\text { employees in } \\
\text { APSRTC." }\end{array}$ & $\begin{array}{l}\text { He found that the provision of } \\
\text { welfare facilities has a positive } \\
\text { impact on the efficiency of } \\
\text { employees. }\end{array}$ \\
\hline
\end{tabular}




\begin{tabular}{|c|c|c|c|c|}
\hline $\begin{array}{c}\text { Serial } \\
\text { no. }\end{array}$ & $\begin{array}{l}\text { Name of } \\
\text { the } \\
\text { author(s) }\end{array}$ & Year & Title of the article & Findings \\
\hline 12 & $\begin{array}{l}\text { Garewal, } \\
\text { K.S. }\end{array}$ & 1978 & $\begin{array}{l}\text { "Dimensions of } \\
\text { Welfare in Coal } \\
\text { Industry" }\end{array}$ & $\begin{array}{l}\text { He stated that the nationalization of } \\
\text { coal industry in } 1973 \text { has brought about } \\
\text { a major change in its operating } \\
\text { philosophy and as a result employee } \\
\text { welfare has been accorded top priority. }\end{array}$ \\
\hline 13 & $\begin{array}{l}\text { Raju and } \\
\text { Jena }\end{array}$ & 2005 & $\begin{array}{l}\text { "Pioneering Welfare } \\
\text { Practices in Oil and } \\
\text { Natural Gas } \\
\text { Corporation } \\
\text { Limited- } \\
\text { Rajahmundry Asset" }\end{array}$ & $\begin{array}{l}\text { They stated that the labour welfare } \\
\text { practices adopted by ONGC contributed } \\
\text { to the economic development in total by } \\
\text { moulding workers into a productive, } \\
\text { efficient and committed labour force. } \\
\text { Further, it has tremendous potentialities } \\
\text { for fostering good industrial relations. }\end{array}$ \\
\hline 14 & $\begin{array}{l}\text { Anjali } \\
\text { Ganesh and } \\
\text { Vijayi D. } \\
\text { Souza }\end{array}$ & 2008 & $\begin{array}{l}\text { "Social Security and } \\
\text { Welfare Measures at } \\
\text { New Mangalore Port } \\
\text { Trust - A Case } \\
\text { Study." }\end{array}$ & $\begin{array}{l}\text { They felt that employees at NMPT are } \\
\text { quite satisfied with the social security } \\
\text { benefits provided by the organization. } \\
\text { They also stated that the provision of } \\
\text { welfare facilities and social security } \\
\text { benefits has a greater influence on the } \\
\text { working of employees through } \\
\text { psychological and social satisfaction. }\end{array}$ \\
\hline 15 & Deepika & 2008 & $\begin{array}{l}\text { "A Relook into the } \\
\text { Measurement of } \\
\text { Human Welfare and } \\
\text { Happiness." }\end{array}$ & $\begin{array}{l}\text { She stated that Governments should } \\
\text { measure the gross National Happiness } \\
\text { (GNH) rather than Gross National } \\
\text { Product (GNP) as gross national } \\
\text { happiness is a better indicator of human } \\
\text { welfare and happiness. }\end{array}$ \\
\hline
\end{tabular}

\section{Research Gap}

From the review of literatures, it is clearly found that many researchers have done several studies on the employees and labour welfare facilities provided by the company or organization and their level of satisfaction of those facilities. There is not a single study on the comparison of the employee's (both executives and non-executives) welfare facilities and their level of satisfaction of those facilities especially in the state of Assam. Hence, to fill up the existing gap the present study is pursued.

\section{Methodology}

In the process of research, methodology occupies an important place. It controls the study, dictates the attainment of the data and arranges it in a logical manner. The research methodology refers to the choice and use of particular strategies and tools for data collection and analysis. The entire process is a unified effort as well an appreciation of its components. 


\section{Objectives of the Study}

The present research enquiry is undertaken with the following objectives:

- $\quad$ To analyze the opinions of the employees in respect of the labour welfare measures \& social security benefits.

- To analyze the level of satisfaction or otherwise of the workers in respect of social security measures.

\section{Research Approach}

The study is descriptive in nature. Hence, descriptive techniques have been used in preparations of the study.

\subsection{Sampling Techniques}

In this study, convenience sampling technique is used as the study is on the "An evaluation of employees welfare facilities of Indian Oil Corporation Limited at Digboi Oil Refinery". Convenience technique is a simple technique where the units that are selected for inclusion in the sample are the easiest to access.

\subsection{Population Unit}

The employees of Indian Oil Corporation Limited of Digboi Oil Refinery and Coal India Limited, Margherita has been taken as the population unit for the survey of this dissertation paper.

\subsection{Population Size}

The size of the population is finite i,e 3102 of the total employees of Indian Oil Corporation Limited of Digboi Oil Refinery including all the departments and Coal India Limited's coalfields at Margherita, as the study is on an evaluation of employees welfare facilities.

\subsection{Sample Size}

In this study, a sample size of 180 (130 Non-executives \& 50 Executives covering almost all the departments) has been taken out of the total population of 3102 employees in both the organisations for the primary data collection in a convenience sample technique for the purpose of the study.

Table 1: Showing the Number of Sample Employees from Selected Organisations

\begin{tabular}{|l|l|l|l|}
\hline Category of Employee & Coal India Limited & Indian Oil Corporation Limited & Total \\
\hline Executives & 23 & 24 & 47 \\
\hline Non- Executives & 98 & 51 & 121 \\
\hline Total & 121 & 75 & 168 \\
\hline
\end{tabular}

Source: Field Survey 


\subsection{Sources of Data}

The data has been collected from both primary data and secondary data. Primary data were collected from the respondents of the employees of Indian Oil Corporation Limited of Digboi Oil Refinery and Coal India Limited, Margherita through the questionnaire method. In this regard, a structured questionnaire was prepared. Secondary data were collected from books, journals, articles, websites etc.

\section{Findings of the Study}

The Researchers have undertaken field study among the employees of IOCL, Digboi and Coal India Limited, Margherita and have interviewed a total of 168 employees comprising of Executives and Non- Executives (Workers, Supervisors, Supporting Staffs) in the month of October, 2016 by personally visiting the organizations. Following are some of the relevant facts that the researchers have been able to derive from the present study:

- Washing Facilities: In case of IOCL, majority of the non-executives (49.09\%) and executives $(45.83 \%)$ are moderately satisfied with the washing facilities provided to them.

Whereas in case of CIL, the Non- Executives are also found to be moderately satisfied with the washing facilities provided to them. They were also of the opinion that they hardly use the washing facilities and as such it didn't really matter to them much.

- Drinking Water Facilities: In case of IOCL, majority (43.64\%) of non-executives are very highly satisfied with the drinking water facilities and $52 \%$ of executives are highly satisfied with the same facilities provided to them. It shows positive effect in the level of their satisfaction.

Most of the Non- Executives (41\%) especially the mine workers, in case of CIL, were found to be dissatisfied with the drinking water facility provided to them at the workplace. The employees also complained about the quality of the drinking water. It was also found out that the level of arsenic content in the water available there is pretty much high.

- $\quad$ First Aid Box: In case of IOCL, majorities (56.36\%) of non-executives are very highly satisfied and $56 \%$ of executives are highly satisfied with the first aid box facility provided to them.

In case of CIL, the non- executives opined that there should be more improvement in the first aid facilities provided to them. As they work in a perilous conditions and thus the facilities should be more than what is provided at present. However, they Executives were of the opinion that the first aid facilities that they are providing are adequate in nature.

- $\quad$ Rest Shelter Facilities: Majority (63.64\%) of both non-executives and executives are moderately satisfied with rest shelter facilities provided to them by the IOCL.

However, the Non- Executives in the mines opined that the rest shelter facilities provided to them are not adequate and there is a huge scope for its improvement.

- Canteen: In this most of the non-executives employees $(45.45 \%)$ are dissatisfied with the quality of food items served in the IOCL canteen in Digboi oil refinery.

Most of the Non- Executives (40\%) opined that the canteen facilities provided to them is very poor. The qualities of the food items are also not good and the environment of 
the canteen is not hygienic and congenial. Very few employees were in favour of the canteen facilities. Most of them viewed the fact there is huge scope of improvement in these aspect.

- Medical Facilities: In this case, most of the non-executives employees are highly satisfied but some $(56 \%)$ of executives employees are moderately dissatisfied regarding non-availability of medicines sometimes, in the IOC, Digboi Refinery Hospital.

Around $33 \%$ of the Executives and Non- Executives were found to be moderately satisfied with regards to the medical facilities available at the Coal India Limited, Margherita. But the Researchers found out that the medical facilities lacked specialist doctors and in case of critical cases the patients had to be shifted elsewhere. Further the dispensaries lacked medicines in number and such many employees were found to be dissatisfied as well with the present facilities.

- Educational Facilities: In this case, the Researchers found out that $43.64 \%$ of nonexecutives and $60 \%$ of executives are satisfied with the present educational facilities provided to the children of the employees of IOCL.

Comparing the same with CIL, the employees were only found out to be moderately satisfied with the said facilities.

- Recreational: In case of IOCL, $45.45 \%$ of non-executives employees are highly satisfied like in indoor facilities such as table tennis, badminton, carom, volley ball and gymnasium. While $32 \%$ of executives are equally moderately satisfied and dissatisfied with the above facilities provided to them.

Coal India Limited also provides some recreational facilities to its employees and both the executives and non- executives had a mixed feeling with regards to the various facilities.

- Housing: Majority (49.09\%) of Non-executives of IOCL were dissatisfied with the housing facilities provided to them.

In case of Coal India Limited, the executives were found to be dissatisfied with regards to the housing Quarter facilities provided to them. They had numerous complains with regards to the quarters provided to them by the company since the constructions are age old and not all spacious. However, the Executives (46\%) responded that they find the housing facilities Good.

- Consumer Cooperative Stores: In case of IOCL, majority i,e $65.45 \%$ of nonexecutives and $48 \%$ of executives are moderately satisfied with the facilities.

But in case of CIL, most of the non- executives were dissatisfied with the consumer co- operative stores. They complained that the goods and commodities are not sold for any rebate. Further, the distance between the quarters of the employees and the cooperative store is quite handsome and that restricts them from visiting the same. The researcher could derive the fact that most of the employees were not availing the benefits of the Consumer Co- Operative stores.

- Cooperative Credit Society: Majority 51.29\% of non-executives are not satisfied with the cooperative credit society given by the IOCL but $36 \%$ of executives are moderately satisfied with the same facility.

Many of the non- executives were found ignorant about the existence of any credit society within the organization. Further they were not found to be knowledgeable about the benefits of such credit societies in CIL. 
- $\quad$ Provident Fund: Majority of the non-executives (49.09\%) are moderately satisfied with the provident fund scheme and $52 \%$ of executives are highly satisfied with the same facilities in IOCL.

In case of CIL, the employees mostly the non- executives (mine workers) were found to be ignorant towards the benefits of such deductions from their salaries. Further, they found such deductions to be expenditures and not savings and investments for future discourse. Some of the employees were frustrated about such deductions due to the lack of knowledge of such social security benefit schemes.

- Gratuity: Majority of the non-executives (58.18\%) are moderately adequate with the gratuity scheme while the majority of executives i,e $60 \%$ are highly adequate with the same scheme.

- Insurance Benefits: Majority (32.73\%) of non-executives employees are very highly satisfied with the insurance schemes followed in the Digboi Oil Refinery.

However, in case of CIL, the non- executives were ignorant towards the existence of such schemes. They were unable to identify any insurance schemes to which they were subscribed.

- Productivity: Majority (76\%) of non-executives are in the opinion that provision of employee welfare and their adequacy helps in increasing the productivity of the refinery.

Maximum of the employees of both executive and non- executive class were found to be of the opinion that the provision of employee welfare and their adequacy have a bearing on the productivity in the coalfields.

- Overall: The Researchers after conducting the study have found out that welfare facilities provided to the non- executives of both the organization is not adequate enough and the employees are only moderately dissatisfied with the different facilities. When comparing the two organizations, it can be concluded that IOCL is providing marginally better facilities to its employees than Coal India Limited.

\section{Suggestions}

After conducting the study, the Researchers would like to put forwards the following suggestions for the betterment of the employees of the concerned Central Public Sector Enterprises (CPSEs):

- In both the organizations, the Researchers could identify the fact there lays a line of difference in their opinions among the different classes of employees with regards to the adequacy level of different welfare measures. As such the researchers would recommend the appropriate body for improving the welfare and social security benefits further so as to improve the quality of life of the employees in various sector as well curbing up such differences.

- Further, in case of Coal India Limited, the Researchers would request the concerned authorities to educate their Non- Executives (specially the mine workers) with regards to the different Social Security schemes and their deductions and its relevance or else such unawareness shall be causing dissatisfaction among the employees.

- Usually the workers in the open cast mines are required to perform their duties in the open and as such the requirement of Rest Shelter facilities is necessitated. However, the Researcher found out that around $7.14 \%$ of the sample respondents in CIL were found to be satisfied with the said facilities. The mine workers are generally exposed to heat, sun 
rays, rain and gifts of Mother Nature because of the nature of works involved in open fields. As a result, a rest shelter facility in certain spots in the mine becomes a necessity.

- Further, most of the workers were found to be dissatisfied with regards to the medical facilities provided to them in both the organizations. Thus, it becomes a necessity for the competent authority to look into the matter and correct the same at the earliest or else the dissatisfaction among the employees is tend to increase. Further, the authority can employ the services of visiting specialist doctors from time to time so that the employees can make up routine checkup rather than going somewhere else at their own cost. This can definitely curb up the unrest.

- Further, the renovation of the housing quarters provided to the employees of CIL is suggested since the buildings are age old and requires attention from the authority at the earliest as the employees seemed to be unhappy from the same.

- The rate of interest fixed up for the Provident fund is age old and requires to be increased since the employees opined that the P.F is not self- sufficient for their sustainability in the near future.

- Proper drinking water facility is necessitated at both the organization since most employees were found to be dissatisfied with the said facility.

- Canteen Facility at the CIL seems to be in a disastrous condition as has been opined by the workers there as such it becomes highly important that the concerned authority takes the grievances of the workers into consideration and provides them with a better and congenial environment specially in the mines with regards to the canteen facility and the food items being served.

- Since most of the employees from CIL are not in the habit of purchasing essential commodities from the Co- Operative stores, the organization needs to take steps to revive the same. The organization is suggested to re- locate the stores at different locations since the mines are wide spread and workers live in different location and the store located at the present place becomes inaccessible. Furthermore, such stores are expected to provide the commodities at a discounted price to its employees but as per the opinion of the respondents, the store does not provide any rebate and as they avoid purchasing from the store.

\section{References}

\section{Books and Dissertations}

[1] Agarwal, S.C., Labour Relations, Law in India, Macmillan Company of India Ltd. 1980

[2] Ahuja.K.K., Personal Management, Kalayani Publishers, New Delhi-1986

[3] Ammssari, P., Workers satisfaction an occupational life, A study of automobile workers in Italy 1964.

[4] Arun Monappa \& Mirza S., Personnel Management. Salyadain, P. 217

[5] Balachandani-K.R., Industrial law, Himalaya Publishing House, Bombay, 1981 Binoy, Mathew., Role of Incentives in Labour Productivity, A case Study of

[6] Selected Public Sector Undertakings in Kerala. Ph.d Thesis, M.G University-June-2003.

[7] Bittel, Lester R., What Every Supervisor Should Know, Mcgraw-Hill Publishing Company, New York, p.249,1974

[8] Blake, Roland (Ed,)., Industrial Safety, Prentice-Hal, New York, 1963, p.300

[9] Chakraborty S.K., Managerial Effectiveness and Quality of Workforce Indianinsights, Tata MC Graw Hill, New Delhi, 1987. 
[10] Chapra. R.N., Public Sector in India, Its Performance Profitability and Industrial relations, Intellectual Publishing House, New Delhi, 1986

[11] Chatterjee N.N., Industrial Relation in public Sector Enterprises in India, Decision, 10(2) pp 10942

[12] Chatterjee S.K., Management of Public Enterprises, Surjeet Publications, 1995.

[13] Chatterjee, N.N., Management of Personnel in Indian Enterprises, Allied Book Agency, Calcutta, 1980.

[14] Cherunilam, Francis., Business Environment, Himalaya Publishing House, Bombay-1978

[15] Das,N., Public Sector in India, Asia Publishing House, Bombay-1966.

[16] Davar R.S., Personnel Management and Industrial Relations, Vikas Publishing House Pvt. Ltd, New Delhi.

[17] Dhyani, S.N., International Labour Organisation and India, National Publishing House, New Delhi, 1977.

[18] Dr. B.P Tyagi., Labour Economics ad Social Welfare., P. 430.

[19] Dr. Bhatnagar., Deepak, Labour Welfare and Social Security Legislation in India, Deep and Deep Publication, New Delhi, 1984

[20] Giri, V.V., Labour Problems in Indian Industry Mumbai: Asia Publishing House. (1972).

[21] Hallen, G., Dynamics of Social Security, Rastogi Publications, Delhi, 1967.

[22] Hamer, Wilie., Occupational Safety, management and Engineering, Prentice-Hal, Englewood Cliffs, 1976, p-104-106.

[23] .

[24] Lallan Prasad and Bannerjee A.M., Management of Human Resources, sterling Publishers Pvt. Ltd, New Delhi, 1994.

[25] Mamoria, C.B., Labour Problems and Social Welfare in India, Kitab Mahal, Allahabad, 1966.

[26] Mamoria, CB, and S. Mamoria., Dynamics of Industrial Relations in India, Himalaya Publishing House, New Delhi, 1995

[27] Mehrotra, B.B.N., Industrial Relations in Public Sector, Commerce annual, No. 1964 pp 130-36

[28] Pareek, udai and T.V Rao., Designing and Managing Human Resource System,

[29] Sherleakar, S.A., Modern Business Organisation and Management, Himalaya Publishing house, Bombay, Oct-1984

[30] Singh, M.M., Social Security and National development, India Book Exchange, Calcutta, 1977.

[31] Vaid. K.N, Labour Welfare in India, Shriram Center for Industrial Relations, New Delhi.1970

\section{Reports}

[1] Government of Bombay, Annual Administration Report of the Factories Act, 1948, p.14, 1957.

[2] International Labour Organisation, Approaches to Social Security, An international Survey, 1942.

[3] International Labour Organisation, Asian Regional Conference Report II, p.3, 1947

[4] International Labour Organisation, Welfare Facilities for Workers in Industry in Western Europe, MEWEL, Geneva,1964.

[5] International Labour Office, Introduction to Social Security, Geneva, 1984

[6] International Labour Organisation, Welfare Facilities for Workers in Industry in Eastern Europe, MEWEL, Geneva, 1964.

[7] Labour Investigation Committee (Main Report), p.352

[8] Report of the Royal Commission on labour, 1931

[9] Report of the National Commission on Labour, 1969

[10] Report of the Committee on Labour Welfare, 1969

[11] Report of the Committee on Labour Welfare, 1969 


\section{Articles}

[1] Acharha, S.R., "Changing Concept of Labour and Management-A new Perspective", Productivity, Vol.32. No.1 January, 1997.

[2] Arun, Kumar, Krishnamurthy, "Productivity Trends in Indian Manufacturing Sector", Productivity, Vol. 42, No.3 Oct/December, 1997

[3] Baig, Mirza, Abrar, "An Empirical Assessment of job Satisfaction and Work Environment", Personnel Today, Vol. II, No. 4, January-March 1991.

[4] Dhavan. R.K., "HRM-Human values and Excellence". Personal Today, Vol XV, No. 2., National Institute of Personnel Management, Calcutta, July-Sep. 1994.

[5] Gangadhar, S.M and Madhar, Keswani, "Changing Nature of Employment and Compensation", Human Capital, Vol. 5 No. 1 June, 2001.

[6] Patra, Ramakanta, "Employee Relations and Business Strategies". HRM Review, The ICFAI University Press, Hyderabad, May-2005.

\footnotetext{
*Corresponding author.

E-mail address: joyjit50@ gmail.com/ sujitsikidar@ gmail.com
} 